Bloom and Postbloom Applications of NAD/NAA Mixture Have Minimal Effects on Yield and Fruit Size of Field-grown Tomatoes and Peppers

\author{
E.W. Stover ${ }^{1}$ and P.J. Stoffella \\ University of Florida, Indian River Research and Education Center, 2199 \\ South Rock Rd., Ft. Pierce, FL 34945-3138
}

S.A. Garrison

Rutgers University, Agricultural Research and Extension Center, 121 Northville, Rd., Bridgeton, NJ 08302-5919

D.I. Leskovar

Texas A\&M University, Agricultural Experiment Station, 1619 Garner Field Rd., Uvalde, TX $78801 a$

D.C. Sanders

North Carolina State University, Dept. of Horticultural Science, Raleigh, NC 27695-7609

\section{C.S. Vavrina}

University of Florida, Southwest Florida Research and Education Center, 2686 State Rd. 29 North, Immokalee, FL 34142-9515

Additional index words. Lycopersicon esculentum, Capsicum annuum, tomato, pepper, 1-naphthaleneacetic acid, 1-naphthaleneacetamide, auxin, growth regulators, PGR

\begin{abstract}
A commercial mixture of 1-naphthaleneacetamide and 1-naphthaleneacetic acid (Amcotone) was applied to tomato (Lycopersicon esculentum Mill.) and pepper (Capsicum annuum $\mathrm{L}$.) at various timings from early bloom through early fruit development to evaluate effects on fruit size and both early and total marketable yield. Amcotone was applied at rates from 10 to $40 \mathrm{mg} \cdot \mathrm{L}^{-1}$, at three sites for each of the species studied. Measured yield response variables in tomato did not differ between the control and Amcotone treatments, regardless of location. Amcotone treatments did not affect yields or fruit size for pepper at the New Jersey or Texas sites. However, at Ft. Pierce, Fla., early marketable yield of pepper was increased in plots receiving three Amcotone applications at $10 \mathrm{mg} \cdot \mathrm{L}^{-1}$, but total marketable yield was significantly reduced in all plots receiving more than two Amcotone sprays, and mean fruit weight was reduced by all Amcotone treatments. Early and total marketable yield of pepper at Ft. Pierce were markedly reduced in plots receiving four applications of $40 \mathrm{mg} \cdot \mathrm{L}^{-1}$, which was a high rate used to assess potential phytotoxicity. While minimal benefit from auxin application was observed in this study, earlier studies suggest that these results may have been influenced by favorable environmental conditions for fruit development or negative effects on unopened flowers during all Amcotone spray applications.
\end{abstract}

Time of production, total marketable yields, and fruit size all contribute to the value of tomato and pepper crops. Recently, researchers working in Europe reported that repeated application of 1-naphthaleneacetic acid (NAA) at $27 \mathrm{mg} \cdot \mathrm{L}^{-1}$ beginning at flower initiation, significantly increased marketable and total yield of greenhouse-grown bell pep-

\footnotetext{
Received for publication 21 Dec. 1999. Accepted for publication 31 Mar. 2000. Florida Agricultural Experiment Station Journal Series No. R-07268. The cost of publishing this paper was defrayed in part by the payment of page charges. Under postal regulations, this paper therefore must be hereby marked advertisement solely to indicate this fact.

${ }^{1}$ To whom requests for reprints should be addressed. E-mail address: ews@gnv.ifas.ufl.edu
}

fruit in Europe and the Middle-East (Wang, personal communication). A range of Amcotone application rates and timings was used at three sites each for peppers and tomatoes to evaluate its potential commercial value.

\section{Materials and Methods}

Tomato cultivars AgriSet 761, Solar Set, and Colonial were grown at the Ft. Pierce, Fla., Immokalee, Fla., and Clinton, N.C. sites, respectively. Pepper cultivars Camelot, Wizard, and Hungarian Wax were grown at the Ft. Pierce, Fla., Bridgeton, N.J., and Uvalde, Texas sites, respectively. Each experiment was arranged as a randomized complete-block design with treatments replicated three or four times. All experimental plots were established in 1998 using standard commercial practices for the growing region. Applications were made to runoff with a hand sprayer or commercial tractor-drawn equipment at total concentrations (a.i.) of 10,20 , and $40 \mathrm{mg} \cdot \mathrm{L}^{-1}$. All plots, except the controls, received designated Amcotone rates at early bloom (first open buds present on all plants in plots) and repeated treatments at 7 to $10 \mathrm{~d}$ intervals. All plots treated with $40 \mathrm{mg} \cdot \mathrm{L}^{-1}$ Amcotone received a total of four applications. For 10 and $20 \mathrm{mg} \cdot \mathrm{L}^{-1}$ Amcotone treatments, plots received either two, three, or four applications. The fourth applications were applied after most fruit had set on all cultivars tested at each location. Fruit of marketable size were harvested from the center section of each plot for a total of three to five harvests at each site. At every harvest date, total fruit number and weight were measured for each plot at each site and mean fruit weight (g/fruit) was recorded, except that only yield was recorded at the site in N. Carolina. Analysis of variance was performed for each measured trait at each site. Significant main effect means were separated by LSD at $P \leq 0.05$.

\section{Results and Discussion}

There were no significant differences between the control and Amcotone treatments for early and total marketable yield or mean fruit weight of tomatoes regardless of location (Table 1). No significant differences among treatments, including the control, were evident for peppers at the New Jersey or Texas sites. However, for peppers at Ft. Pierce, Fla., early marketable yield was increased in plots receiving three Amcotone applications at $10 \mathrm{mg} \cdot \mathrm{L}^{-1}$, but total marketable yield was significantly reduced in all plots receiving more than two Amcotone sprays, and mean fruit weight was reduced by all Amcotone treatments. Early and total marketable yield of peppers at Ft. Pierce were markedly reduced in plots receiving four applications of $40 \mathrm{mg} \cdot \mathrm{L}^{-1}$. Note that $40 \mathrm{mg} \cdot \mathrm{L}^{-1}$ exceeds the labeled use rate for Amcotone.

Early studies on auxin enhancement of tomato production indicated that locule filling and fruit size were increased in poorly pollinated, winter-grown greenhouse fruit (Howlett, 1942), and fruit set was increased 
Table 1. Effects of Amcotone (24 NAD : 9 NAA mixture) applications on yield and fruit weight of tomatoes and peppers at three locations.

\begin{tabular}{|c|c|c|c|c|c|c|c|}
\hline \multirow[b]{2}{*}{$\begin{array}{l}\text { Amcotone } \\
\left(\mathrm{mg} \cdot \mathrm{L}^{-1}\right)^{\mathrm{z}}\end{array}$} & \multirow[b]{2}{*}{$\begin{array}{l}\text { Times of } \\
\text { application }\end{array}$} & \multicolumn{3}{|c|}{ Tomatoes } & \multicolumn{3}{|c|}{ Peppers } \\
\hline & & $\begin{array}{c}\text { Ft. Pierce } \\
\text { Fla. }\end{array}$ & $\begin{array}{c}\text { Immakolee } \\
\text { Fla. }\end{array}$ & $\begin{array}{l}\text { Clinton } \\
\text { N.C. }\end{array}$ & $\begin{array}{c}\text { Ft. Pierce } \\
\text { Fla. }\end{array}$ & $\begin{array}{c}\text { Bridgeton } \\
\text { N.J. }\end{array}$ & $\begin{array}{c}\text { Uvalde } \\
\text { Texas }\end{array}$ \\
\hline & & & Early $n$ & arketable & eld $\left(\mathrm{mg} \cdot \mathrm{ha}^{-1}\right)$ & & \\
\hline 0 & & 4.8 & 28.4 & 14.9 & 34.3 & 27.2 & 7.7 \\
\hline \multirow[t]{3}{*}{10} & EM & 4.2 & 26.5 & 14.4 & 35.6 & 28.9 & 7.2 \\
\hline & EML & 6.0 & 28.5 & 14.4 & 36.9 & 29.0 & 8.4 \\
\hline & EMLF & 6.0 & 26.9 & 14.3 & 36.2 & 30.1 & 6.6 \\
\hline \multirow[t]{3}{*}{20} & EM & 6.8 & 27.2 & 12.9 & 33.7 & 29.1 & 6.9 \\
\hline & EML & 5.5 & 26.6 & 15.4 & 34.2 & 24.7 & 8.3 \\
\hline & EMLF & 6.5 & 26.2 & 17.2 & 33.9 & 28.1 & 6.9 \\
\hline \multirow[t]{3}{*}{40} & EMLF & 2.7 & 28.1 & 14.1 & 28.5 & 27.1 & 7.6 \\
\hline & $\mathrm{LSD}_{0.05}$ & NS & NS & 3.6 & 2.5 & NS & NS \\
\hline & & & - Total n & arketable & eld $\left(m g \cdot h^{-1}\right)$ & & \\
\hline 0 & & 10.2 & 61.3 & 35.7 & 56.7 & 43.1 & 14.3 \\
\hline \multirow[t]{3}{*}{10} & EM & 12.0 & 59.1 & 37.8 & 51.9 & 46.2 & 11.6 \\
\hline & EML & 14.0 & 59.6 & 38.9 & 50.7 & 41.4 & 13 \\
\hline & EMLF & 13.3 & 61.6 & 39.0 & 50.6 & 46.5 & 11.6 \\
\hline \multirow[t]{3}{*}{20} & EM & 14.0 & 62.1 & 36.5 & 51.9 & 46.8 & 10.9 \\
\hline & EML & 11.6 & 57.1 & 33.8 & 48.5 & 37.7 & 12.7 \\
\hline & EMLF & 14.6 & 56.8 & 38.9 & 47.8 & 43.0 & 11.5 \\
\hline \multirow[t]{2}{*}{40} & EMLF & 8.3 & 61.4 & 36.1 & 43.6 & 43.1 & 12.1 \\
\hline & $\mathrm{LSD}_{0.05}$ & NS & NS & \multicolumn{2}{|c|}{$\begin{array}{l}\mathrm{NS} \\
\mathrm{Wt} / \text { fruit }(\mathrm{g})\end{array}$} & NS & NS \\
\hline 0 & & 136 & 157 & --- & 154 & 186 & 122 \\
\hline \multirow[t]{3}{*}{10} & EM & 138 & 158 & --- & 144 & 191 & 118 \\
\hline & EML & 143 & 159 & --- & 140 & 191 & 124 \\
\hline & EMLF & 137 & 158 & --- & 141 & 191 & 120 \\
\hline \multirow[t]{3}{*}{20} & EM & 146 & 158 & --- & 141 & 186 & 135 \\
\hline & EML & 146 & 160 & --- & 141 & 186 & 132 \\
\hline & EMLF & 142 & 158 & --- & 139 & 181 & 118 \\
\hline \multirow[t]{2}{*}{40} & EMLF & 137 & 159 & --- & 139 & 181 & 125 \\
\hline & $\mathrm{LSD}_{0.05}$ & NS & NS & --- & 8.5 & NS & NS \\
\hline
\end{tabular}

${ }^{\mathrm{z}} \mathrm{Amcotone}$ rate designated is combined NAAm and NAA.

${ }^{\mathrm{y}} \mathrm{EM}=$ application at early and mid flowering, $\mathrm{EML}=$ application at early, mid, and late flowering, and $\mathrm{EMLF}=$ application at early, mid, and late flowering, and early fruiting.

outdoors only when low night temperatures were not conducive to fruit set (Moore, 1950; Wittwer and Schmidt, 1950). Auxin sprays apparently permitted more normal development when plant development was compromised by environmental conditions. Also, Hemphill (1949) reported that spraying auxin on fully opened tomato flowers was beneficial, but application to unopened flowers often reduced fruit size and set. The lack of yield and fruit size enhancement by auxin sprays reported here may have resulted from growing conditions in which the control plants were not limited by poor pollination, cool night-time temperatures, or other environmental stresses. Also, many unopened flowers were treated in this study, since sprays were applied to entire plants, and any positive auxin effects on opened flowers may have been countered by deleterious effects on unopened flowers. Environmental conditions, cultural practices such as irrigation or fertilization, or application timing may significantly influence response of tomatoes and peppers to auxin sprays. Clearly, the application rates and timings used in this study do not warrant commercial use in similar conditions, although earlier studies suggest that there are situations where auxin treatments may be beneficial.

\section{Literature Cited}

Belakbir, A., J.M. Ruiz, and L. Romero. 1998. Yield and fruit quality of pepper (Capsicum anпиит L.) in response to bioregulators. HortScience 33:85-87.

Hemphill, D.D. 1949. The importance of time of application of "hormone" sprays to improve greenhouse tomato yields. Proc. Amer. Soc. Hort. Sci. 54:261-264.

Howlett, F.S. 1942. Fruit set and development from pollinated tomato flowers treated with indolebutyric acid. Proc. Amer. Soc. Hort. Sci. 41:277281.

Moore, J.F. 1950. Use of para-chlorophenoxyacetic acid spray and two pruning systems to increase yield and fruit size of field-grown tomatoes in western Washington. Proc. Amer. Soc. Hort. Sci. 56:299-302.

Murneek, A.E. 1947. Results of further investigations on the use of "hormone" sprays on tomato culture. Proc. Amer. Soc. Hort. Sci. 50:254 262.

Murneek, A.E., S.H. Wittwer, and D.H. Hemphill. 1944. Supplementary "hormone" sprays for greenhouse grown tomatoes. Proc. Amer. Soc. Hort. Sci. 45:371-381.

Wittwer, S.H. and W.A. Schmidt. 1950. Further investigations of the effects of "hormone" sprays on the fruiting response of outdoor tomatoes. Proc. Amer. Soc. Hort. Sci. 55:335-342. 